The Journal of Animal \& Plant Sciences, 31(4): 2021, Page: 966-973

ISSN (print): 1018-7081; ISSN (online): 2309-8694

\title{
EFFECTS OF IMMUNE MODULATORS ON GROWTH AND ECONOMIC PERFORMANCE OF BROILER CHICKENS
}

\author{
I. S. Sheikh ${ }^{1}$, T. M. Asmat ${ }^{1 *}$, M. A. Bajwa ${ }^{1}$, M. Z. Mustafa ${ }^{1}$, N. Rashid ${ }^{1}$, M. Rafeeq ${ }^{1}$, M. M. T. Kiani ${ }^{1}$, H. M. Ali ${ }^{2}$ and \\ A. Raziq ${ }^{3}$ \\ ${ }^{1}$ Center for Advanced Studies in Vaccinology and Biotechnology (CASVAB), University of Balochistan, Quetta, \\ Pakistan \\ ${ }^{2}$ University College of Veterinary and Animal Sciences, Islamia University of Bahawalpur. \\ ${ }^{3}$ Department of Statistics, University of Balochistan, Quetta, Pakistan. \\ *Correspondence author's email: tauseefcasvab@gmail.com
}

\begin{abstract}
Immune modulators have been found beneficial for growth performance, physiological status, and immune function in broilers. Imbalance between pro-oxidants and anti-oxidants creates oxidative stress in fast growing broiler birds. Immune modulators are capable of reducing oxidative stress produced by excess production of ROS/RNS in rapidly growing body. The current project was designed to study the effects of supplementing different immune modulators on growth performance indices in broiler chicken in 3 separate experiments ( $\mathrm{n}=240$ chicks in each experiment). Immune modulators viz. vitamin C $(500 \mathrm{mg} / \mathrm{L})$, vitamin E $(200 \mathrm{mg} / \mathrm{L})$, nucleotides mixture $(100 \mathrm{mg} / \mathrm{L})$ and DNA extract $(100 \mathrm{mg} / \mathrm{L})$ were provided through drinking water. In the experiment I, immune modulators were offered only from day 1 to 21. In experiment II, immune modulators were supplemented for complete rearing period i.e. from day 1 to 42 ; whereas in the experiment III, immune modulators were only provided from day 22 to 42 . Supplementation of immunomodulators revealed significantly $(\mathrm{P}<0.05)$ higher live body weight gain and better feed conversion ratio as compared to control group. Over all nucleotides performed more efficiently compared to other used immunomodulators in all three experiments with better feed conversion ratio. It was thus concluded from the study that the provision of immune boosters in starter or finisher phase simultaneously improved production indices and economic performance of broiler chickens.
\end{abstract}

Key words: growth performance, immune modulators, nucleotides, vitamin C, vitamin $\mathrm{E}$

https://doi.org/10.36899/JAPS.2021.4.0292

Published online December 18, 2020

\section{INTRODUCTION}

Commercial broiler farming is influenced by various environmental, biological and nutritional stressors causing deregulations of physiological/homeostasis processes (Corsello et al. 2018; Santoro, 2018) results in compromised physiological and immune status and declined productive performance of broiler chickens (Surai et al., 2019). Excessive production of free radicals adversely influences antioxidant defense system, resulting in oxidative stress (Corsello et al., 2018; Santoro, 2018). Various feed additives can be supplemented as nutritional elements for enhancing protective competency of birds with beneficial immunomodulatory and stress releasing properties (Kuldeep et al., 2014). Generally, farmers and feed manufacturers use antibiotics as growth promoting agents to get better feed efficiency and to minimize the mortality. These practices may result in antibiotic resistant microorganisms' species due to which certain restrictions has been imposed on poultry industry for the judicious use of antibiotics as growth promoters (Rafeeq et al., 2017). Strict regulations and increasing consumer concerns regarding the use of antibiotics as growth promoters in the poultry production, have thrown the industry under mounting pressure to limit its use in broiler chicken production before marketing. The denial to the application of antibiotics as growth promoter is leading to higher disease out breaks and declined production performance in the developing countries where still open shed conventional farming system is the common way of broiler production (Huff et al., 2013a).

Supplementation with phytochemicals (Valenzuela-grijalva et al., 2017), dietary symbiotics (Chen et al., 2018), vitamin and minerals (Watson et al., 2016) and antioxidants, such as vitamin E, vitamin C (Sheikh et al., 2020) have become an essential component of the poultry diets to cope the physiological requirements of stressed birds, that may also work as growth promoting agents, an alternative to antibiotics. Hence, it is a thought-provoking job to develop a method of judicious antioxidant supplementation to support growth in broiler chickens and to sustain effective antioxidant defense and redox balance in the body.

The main source of vitamin $\mathrm{E}$ is double lipid cell membrane that is closely resembling to oxidase enzymes, 
responsible to produce free radicals (Sahin and Kucuk, 2001; Sahin et al., 2003). Main chain-breaking antioxidants particularly polyunsaturated fatty acids protect the cell membranes and tissues from the damage of free radicals (Vlojc et al., 2011). Similarly, vitamin C is also found to be useful in inhibiting copper-induced oxidative harm in poultry birds (Ajuwon and Idowu, 2010). Supplementation of such modulators in diets may enhance health conditions and growth performance, enabling economic benefits.

The scenario creates a dire need for finding alternative ways to control the diseases with least dependency on the use of antibiotics. A number of prospective immune modulators are of worth use as substitute to antibiotics that are not only giving growth boost but also defending the birds against the diseases (D'Costa et al., 2011). In this regard immunomodulators having antioxidant properties might be a good option that will enhance immune functions (Sheikh et al., 2020), improves growth performance and meet quality (Chen et al.. 2018). The current study was conceded to compare the role of different immune modulators on growth improvement and their economic impact in broiler chickens.

\section{MATERIALS AND METHODS}

Three experiments were conducted simultaneously with day old Hubbard broiler chickens ( $n=240 /$ experiment) divided into five groups of 48 chicks. Each treatment group was further replicated 4 times (12 chicks/replicate). The group one was kept as control and offered basal diet and plain water (no treatment in drinking water, whereas treatment groups two, three, four and five viz vitamin C $(500 \mathrm{mg} / \mathrm{L})$, vitamin E $(200 \mathrm{mg} / \mathrm{L})$, Saccharomyces cerevisiae nucleotides $(100 \mathrm{mg} / \mathrm{L})$ and DNA, extracted from chicken liver $(100 \mathrm{mg} / \mathrm{L})$ respectively were offered basal diet and immunomodulators in drinking water. The birds were kept under standard management conditions and were offered basal diet i.e. Pre-starter feed during first 12 days, continued with starter feed from day $13^{\text {th }}$ to $25^{\text {th }}$ and thereafter till the end of trial with finisher feed unanimously to all treatment groups. The drinking water was provided ad-libitum and the experimental shed temperature was maintained initially at about $95^{\circ} \mathrm{F}$ during first week then gradually decreased $5^{\circ} \mathrm{F} /$ week till $70-75$ ${ }^{\circ} \mathrm{F}$ at $5^{\text {th }}$ and $6^{\text {th }}$ weeks of age. All the experimental birds were vaccinated against Newcastle disease virus (NDV) at $7^{\text {th }}$ and $21^{\text {st }}$ days of age and for infectious bursal disease virus (IBDV) at day $14^{\text {th }}$ and $28^{\text {th }}$.

In the experiment I, immunomodulators treated water was offered from day 1 to 21 (starter phase). In experiment II immune modulators were offered throughout 1-42 days of rearing period and in experiment III immune modulators treated drinking water was commenced from day $22^{\text {nd }}$ and continued till day 42 (finisher phase). At the end of experiments (day $42^{\text {nd }}$ ) 12 birds from each group (3 birds/replicate) were humanely slaughtered. Growth performance parameters; average weight gain (AWG), feed conversion ratio (FCR), feed intake (FI) was evaluated on the weekly basis whereas, dressing percentage (DP) and relative organ weight (ROW) were recorded on day 42 (Owosibo et al., 2013).

Economic efficiency of these immune modulators was evaluated using European Production Efficiency Factor (EPEF) following the methodology reported previously (Huff et al., 2013b).

$\mathrm{EPEF}=$ Mean Live Body Weight $(\mathrm{kg}) \times$ Livability $(\%) \times$ 100

Age $\times$ FCR

Statistical analysis: Collected data were analyzed using one-way analysis of variance (ANOVA) using statistical analysis software SPSS 20 for Windows, and to compare means of the treatments by applying Duncan's Multiple Range test. The results were presented as mean $\pm \mathrm{SE}$.

\section{RESULTS}

Experiment I: The results of experiment 1 are given in Table 1. The weight gain during starter phase of experiment I showed a significant difference $(\mathrm{P}<0.05)$ among the treatment groups. Highest weight gain $(723.92 \pm 4.46 \mathrm{gm})$, ADG $(34.47 \pm 0.21 \mathrm{gm})$ and improved FCR $(1.18 \pm 0.01)$ were noted in the group supplemented with nucleotides. In this phase, weight gain of other groups including vitamin $\mathrm{C}$, vitamin $\mathrm{E}, \mathrm{DNA}$ and control were noted $702.14 \pm 3.01,708.55 \pm 7.29,696.41 \pm 11.07$ and $681.09 \pm 6.15$ respectively. During the finisher phase of experiment, I, non-significant effects were observed regarding $\mathrm{AWG}, \mathrm{ADG}$ and $\mathrm{FCR}$ on growth parameters. In experiment I, significant effect on overall growth performance of nucleotide, vitamin $\mathrm{C}$, vitamin $\mathrm{E}$ and DNA supplemented groups was observed as compared to control. The effect of immune modulator on relative organ weight (ROW) of liver, gizzard, proventiculous, intestinal length and carcass percentage at the end of experiment was noted non-significant $(\mathrm{P}>0.05)$ among treatments (Table 4). 
Table 1. Body weight gain (gm), feed intake (gm), feed conversion ratio (FCR) and average daily weight gain (ADG) during different phases of Experiment 1.

\begin{tabular}{|c|c|c|c|c|c|}
\hline & Treatments & $\begin{array}{c}\text { Weight } \\
\text { gain (gm) }\end{array}$ & Feed intake (gm) & FCR & $\begin{array}{l}\text { ADG } \\
\text { (gm) }\end{array}$ \\
\hline \multirow{6}{*}{$\begin{array}{c}\text { Starter } \\
\text { Phase (1-21 } \\
\text { days) }\end{array}$} & Control & $681.09 \pm 6.15^{\mathrm{c}}$ & $866.25 \pm 5.39$ & $1.27 \pm 0.01^{\mathrm{a}}$ & $32.43 \pm 0.29^{c}$ \\
\hline & Vitamin $\mathrm{C}$ & $702.14 \pm 3.01^{\mathrm{ab}}$ & $864.75 \pm 7.39$ & $1.23 \pm 0.01^{\mathrm{ab}}$ & $33.44 \pm 0.14^{\mathrm{ab}}$ \\
\hline & Vitamin E & $708.55 \pm 7.29^{\mathrm{ab}}$ & $861.50 \pm 8.11$ & $1.22 \pm 0.02^{\mathrm{bc}}$ & $33.74 \pm 0.35^{\mathrm{ab}}$ \\
\hline & Nucleotides & $723.92 \pm 4.46^{\mathrm{a}}$ & $855.25 \pm 4.52$ & $1.18 \pm 0.01^{\mathrm{c}}$ & $34.47 \pm 0.21^{\mathrm{a}}$ \\
\hline & DNA & $696.41 \pm 11.07^{\mathrm{bc}}$ & $847.25 \pm 8.96$ & $1.22 \pm 0.01^{\mathrm{bc}}$ & $33.16 \pm 0.5^{\mathrm{bc}}$ \\
\hline & Control & $1774.03 \pm 25.84$ & $2939.75 \pm 6.57$ & $1.66 \pm 0.02$ & $84.48 \pm 1.23$ \\
\hline \multirow{4}{*}{$\begin{array}{c}\text { Finisher } \\
\text { Phase (22- } \\
42 \text { days) }\end{array}$} & Vitamin $\mathrm{C}$ & $1821.33 \pm 14.32$ & $2925.75 \pm 9.45$ & $1.61 \pm 0.01$ & $86.73 \pm 0.68$ \\
\hline & Vitamin E & $1807.19 \pm 13.80$ & $2934.75 \pm 8.27$ & $1.62 \pm 0.00$ & $86.06 \pm 0.66$ \\
\hline & Nucleotides & $1850.53 \pm 20.92$ & $2928.75 \pm 6.34$ & $1.58 \pm 0.02$ & $88.12 \pm 0.99$ \\
\hline & DNA & $1833.58 \pm 18.17$ & $2924.50 \pm 15.88$ & $1.59 \pm 0.02$ & $87.31 \pm 0.87$ \\
\hline \multirow{5}{*}{$\begin{array}{c}\text { Overall (1- } \\
42 \text { days) }\end{array}$} & Control & $2455.12 \pm 20.44^{\mathrm{c}}$ & $3806.00 \pm 9.34$ & $1.55 \pm 0.02^{\mathrm{a}}$ & $58.46 \pm 0.49^{c}$ \\
\hline & Vitamin $\mathrm{C}$ & $2523.48 \pm 12.78^{\mathrm{ab}}$ & $3790.50 \pm 5.87$ & $1.50 \pm 0.01^{\mathrm{bc}}$ & $60.08 \pm 0.33^{\mathrm{ab}}$ \\
\hline & Vitamin E & $2515.74 \pm 15.91^{\mathrm{b}}$ & $3796.25 \pm 12.67$ & $1.51 \pm 0.01^{b c}$ & $59.90 \pm 0.38^{\mathrm{b}}$ \\
\hline & Nucleotides & $2574.45 \pm 17.71^{\mathrm{a}}$ & $3784.00 \pm 3.08$ & $1.47 \pm 0.01^{\mathrm{c}}$ & $61.30 \pm 0.29^{\mathrm{a}}$ \\
\hline & DNA & $2529.98 \pm 12.53^{\mathrm{ab}}$ & $3771.75 \pm 24.71$ & $1.49 \pm 0.01^{\mathrm{bc}}$ & $60.23 \pm 0.20^{\mathrm{ab}}$ \\
\hline
\end{tabular}

abc Shows in the same row with different superscripts are significantly different $(\mathrm{P}<0.05)$.

Experiment II: The results of broiler chicken performance of experiment 2 are presented in Table 2. In $2^{\text {nd }}$ experiment, immune modulators were supplemented throughout the rearing period (day 1 to 42 ). The average weight gain during the starter phase showed a significant difference $(\mathrm{P}<0.05)$ among the treatment groups. In starter phase, highest weight gain $(724.90 \pm 6.84 \mathrm{gm})$, ADG (34.52 $\pm 0.33 \mathrm{gm})$ and improved FCR $(1.19 \pm 0.01)$ were gained in group supplemented with nucleotides while non-significant difference was observed within vitamin $\mathrm{C}$, vitamin $\mathrm{E}$ and DNA supplemented groups. During finisher phase, supplementation of vitamin C, vitamin $\mathrm{E}$, nucleotides and DNA showed significant difference $(\mathrm{P}<0.05)$ on growth parameters in comparison to control while non-significant difference within all immune modulator supplemented groups. The results of growth indices at the end of the experiment (day 42) showed significant difference $(\mathrm{P}<0.05)$ among various treatments. Highest average weight gain $(2526.56 \pm 15.76 \mathrm{gm})$, ADG $(60.16 \pm 0.38 \mathrm{gm})$ and lowest FCR $(1.50 \pm 0.01)$ was noted in group supplemented with nucleotides while non-significant difference in comparison to other immune modulators used in the experiment. The impact of immune modulator on ROW (Table 4) during the experiment was also non-significant $(\mathrm{P}>0.05)$.
Experiment III: In the $3^{\text {rd }}$ experiment, immune modulators were supplemented in drinking water only during finisher phase i.e. from day $22^{\text {nd }}$ to $42^{\text {nd }}$. The results of growth parameters are presented in Table 3 . Initially, no significant differences in WG, FI, FCR and ADG were noted during starter phase. While at the end of the finisher phase, treatment groups supplemented with immunomodulators showed significantly $(\mathrm{P}<0.05)$ higher WG, ADG and improved FCR compared to control group. However, immunomodulators supplemented groups revealed a non-significant $(\mathrm{P}>0.05)$ difference

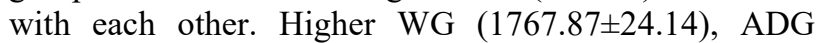
$(84.18 \pm 1.15)$ and FCR $(1.66 \pm 0.03)$ were observed in vitamin $\mathrm{E}$ supplemented group. The results regarding the effect of immune modulators on intestinal length, carcass percentage and ROW of liver, gizzard, and proventiculous, revealed a non-significant $(\mathrm{P}>0.05)$ difference among groups (Table 4).

Economic performance: Economic efficiency of these immune modulators was evaluated in terms of European Production Efficiency Factor is given in Table 5. In all three experiments highest EPEF values 384, 384 and 357 were observed in experiment I, II and III respectively in nucleotide supplemented groups whereas lowest EPEF values (341, 337 and 300) were observed in control groups. 
Table 2. Body weight gain (gm), feed intake (gm), feed conversion ratio (FCR) and average daily weight gain (ADG) during different phases of Experiment II.

\begin{tabular}{|c|c|c|c|c|c|}
\hline & Treatments & Weight gain (gm) & $\begin{array}{l}\text { Feed intake } \\
\text { (gm) }\end{array}$ & FCR & $\begin{array}{c}\text { ADG } \\
(\mathrm{gm})\end{array}$ \\
\hline & Control & $685.38 \pm 5.82^{c}$ & $868.75 \pm 3.04$ & $1.27 \pm 0.01^{\mathrm{a}}$ & $32.64 \pm 0.28^{c}$ \\
\hline Starter & Vitamin C & $701.64 \pm 4.80^{\mathrm{ab}}$ & $870.25 \pm 7.25$ & $1.24 \pm 0.01^{\mathrm{ab}}$ & $33.41 \pm 0.23^{b c}$ \\
\hline \multirow{4}{*}{$\begin{array}{c}\text { Phase (1-21 } \\
\text { days) }\end{array}$} & Vitamin E & $716.92 \pm 5.54^{\mathrm{ab}}$ & $869.00 \pm 5.08$ & $1.21 \pm 0.02^{\mathrm{bc}}$ & $34.14 \pm 0.26^{\mathrm{ab}}$ \\
\hline & Nucleotides & $724.90 \pm 6.84^{\mathrm{a}}$ & $860.00 \pm 3.08$ & $1.19 \pm 0.01^{\mathrm{c}}$ & $34.52 \pm 0.33^{\mathrm{a}}$ \\
\hline & DNA & $713.03 \pm 4.37^{\mathrm{ab}}$ & $863.00 \pm 10.59$ & $1.21 \pm 0.02^{\mathrm{bc}}$ & $33.96 \pm 0.21^{\mathrm{ab}}$ \\
\hline & Control & $1736.55 \pm 10.58^{b}$ & $2938.25 \pm 10.87$ & $1.69 \pm 0.01^{\mathrm{a}}$ & $82.69 \pm 0.50^{b}$ \\
\hline Finisher & Vitamin C & $1801.38 \pm 22.35^{\mathrm{a}}$ & $2941.25 \pm 5.66$ & $1.63 \pm 0.02^{\mathrm{b}}$ & $85.78 \pm 1.06^{\mathrm{a}}$ \\
\hline \multirow{4}{*}{$\begin{array}{l}\text { Phase (22- } \\
42 \text { days) }\end{array}$} & Vitamin E & $1801.20 \pm 16.53^{\mathrm{a}}$ & $2938.75 \pm 5.27$ & $1.63 \pm 0.01^{\mathrm{b}}$ & $85.77 \pm 0.79^{a}$ \\
\hline & Nucleotides & $1804.66 \pm 13.62^{a}$ & $2948.25 \pm 9.42$ & $1.63 \pm 0.02^{\mathrm{b}}$ & $85.79 \pm 0.65^{\mathrm{a}}$ \\
\hline & DNA & $1802.65 \pm 15.93^{\mathrm{a}}$ & $2950.00 \pm 10.21$ & $1.63 \pm 0.01^{\mathrm{b}}$ & $85.84 \pm 0.76^{\mathrm{a}}$ \\
\hline & Control & $2421.93 \pm 6.40^{\mathrm{b}}$ & $3807.00 \pm 8.80$ & $1.57 \pm 0.00^{\mathrm{a}}$ & $57.67 \pm 0.15^{\mathrm{b}}$ \\
\hline \multirow{4}{*}{$\begin{array}{c}\text { Total (1-42 } \\
\text { days) }\end{array}$} & Vitamin C & $2503.02 \pm 18.29^{\mathrm{a}}$ & $3811.50 \pm 9.97$ & $1.52 \pm 0.01^{\mathrm{b}}$ & $59.60 \pm 0.44^{\mathrm{a}}$ \\
\hline & Vitamin E & $2518.12 \pm 21.0^{\mathrm{a}}$ & $3807.75 \pm 2.10$ & $1.51 \pm 0.01^{\mathrm{b}}$ & $59.95 \pm 0.50^{\mathrm{a}}$ \\
\hline & Nucleotides & $2526.56 \pm 15.76^{\mathrm{a}}$ & $3808.25 \pm 3808$ & $1.50 \pm 0.01^{\mathrm{b}}$ & $60.16 \pm 0.38^{\mathrm{a}}$ \\
\hline & DNA & $2515.81 \pm 15.97^{\mathrm{a}}$ & $3813.00 \pm 17.76$ & $1.51 \pm 0.01^{\mathrm{b}}$ & $59.90 \pm 0.38^{\mathrm{a}}$ \\
\hline
\end{tabular}

abc Shows in the same row with different superscripts are significantly different $(\mathrm{P}<0.05)$.

Table 3. Body weight gain (gm), feed intake (gm), feed conversion ratio (FCR) and average daily weight gain (ADG) during different phases of experiment III.

\begin{tabular}{cccccc}
\hline & Treatments & $\begin{array}{c}\text { Weight gain } \\
(\mathbf{g m})\end{array}$ & $\begin{array}{c}\text { Feed intake } \\
(\mathbf{g m})\end{array}$ & FCR & $\begin{array}{c}\text { ADG } \\
(\mathbf{g m})\end{array}$ \\
\hline & Control & $667.83 \pm 6.35$ & $867.25 \pm 4.94$ & $1.29 \pm 0.02$ & $31.80 \pm 0.30$ \\
Starter & Vitamin C & $680.31 \pm 6.68$ & $868.25 \pm 13.31$ & $1.28 \pm 0.03$ & $32.40 \pm 0.32$ \\
Phase (1- & Vitamin E & $692.68 \pm 6.18$ & $865.00 \pm 6.79$ & $1.25 \pm 0.02$ & $32.98 \pm 0.29$ \\
21 days) & Nucleotides & $686.63 \pm 14.22$ & $852.00 \pm 5.45$ & $1.24 \pm 0.02$ & $32.70 \pm 0.68$ \\
& DNA & $675.33 \pm 13.13$ & $843.00 \pm 8.88$ & $1.25 \pm 0.03$ & $32.16 \pm 0.63$ \\
Finisher & Control & $1677.38 \pm 6.50^{\mathrm{b}}$ & $2953.00 \pm 4.26$ & $1.77 \pm 0.00^{\mathrm{a}}$ & $79.87 \pm 0.31^{\mathrm{b}}$ \\
Phase (22- & Vitamin C & $1754.45 \pm 7.82^{\mathrm{a}}$ & $2942.75 \pm 14.63$ & $1.68 \pm 0.01^{\mathrm{b}}$ & $83.55 \pm 0.37^{\mathrm{a}}$ \\
42 days) & Vitamin E & $1767.87 \pm 24.14^{\mathrm{a}}$ & $2931.25 \pm 8.87$ & $1.66 \pm 0.03^{\mathrm{b}}$ & $84.18 \pm 1.15^{\mathrm{a}}$ \\
& Nucleotides & $1755.71 \pm 14.26^{\mathrm{a}}$ & $2963.50 \pm 1.94$ & $1.69 \pm 0.01^{\mathrm{b}}$ & $83.61 \pm 0.68^{\mathrm{a}}$ \\
& DNA & $1756.37 \pm 13.54^{\mathrm{a}}$ & $2949.00 \pm 6.52$ & $1.68 \pm 0.01^{\mathrm{b}}$ & $83.64 \pm 0.64^{\mathrm{a}}$ \\
Total (1-42 & Control & $2345.21 \pm 11.92^{\mathrm{b}}$ & $3820.25 \pm 6.57$ & $1.63 \pm 0.01^{\mathrm{a}}$ & $55.84 \pm 0.28^{\mathrm{b}}$ \\
days) & Vitamin C & $2434.75 \pm 10.27^{\mathrm{a}}$ & $3811.00 \pm 14.46$ & $1.57 \pm 0.01^{\mathrm{b}}$ & $57.97 \pm 0.24^{\mathrm{a}}$ \\
& Vitamin E & $2460.55 \pm 20.70^{\mathrm{a}}$ & $3796.25 \pm 12.70$ & $1.54 \pm 0.02^{\mathrm{b}}$ & $58.58 \pm 0.49^{\mathrm{a}}$ \\
& Nucleotides & $2442.34 \pm 12.38^{\mathrm{a}}$ & $3815.50 \pm 4.25$ & $1.56 \pm 0.01^{\mathrm{b}}$ & $58.15 \pm 0.29 \mathrm{a}^{\mathrm{a}}$ \\
\hline
\end{tabular}

${ }^{\mathrm{ab}}$ Shows in the same row with different superscripts are significantly different $(\mathrm{P}<0.05)$.

Table 4. Relative weights (\%) of body organs of Experiment I, Experiment II and Experiment III under the effects of different treatments.

\begin{tabular}{cccccccc}
\hline & Treatments & Liver & \multicolumn{1}{c}{ Heart } & Gizzard & Proventiculous & Intestine & $\begin{array}{c}\text { Carcass } \\
\text { Percentage }\end{array}$ \\
\hline & Control & $0.0233 \pm 0.0008$ & $0.005 \pm 0.0005$ & $0.025 \pm 0.001$ & $0.003 \pm 0.0002$ & $6.719 \pm 0.29$ & $62.20 \pm 0.509$ \\
& Vitamin C & $0.0225 \pm 0.0009$ & $0.0048 \pm 0.003$ & $0.025 \pm 0.002$ & $0.0048 \pm 0.0009$ & $7.689 \pm 0.32$ & $61.14 \pm 0.638$ \\
I & Vitamin E & $0.0218 \pm 0.0007$ & $0.005 \pm 0.0004$ & $0.022 \pm 0.002$ & $0.003 \pm 0.0003$ & $7.56 \pm 0.61$ & $62.56 \pm 0.194$ \\
& Nucleotides & $0.0228 \pm 0.0016$ & $0.0048 \pm 0.0003$ & $0.0266 \pm 0.002$ & $0.0039 \pm 0.0003$ & $7.72 \pm 0.27$ & $62.69 \pm 3.279$ \\
& DNA & $0.023 \pm 0.0009$ & $0.005 \pm 0.0001$ & $0.026 \pm 0.002$ & $0.0040 \pm 0.0002$ & $7.032 \pm 0.20$ & $61.28 \pm 0.896$ \\
II & Control & $0.022 \pm 0.001$ & $0.0043 \pm 0.0002$ & $0.0282 \pm 0.001$ & $0.005 \pm 0.0002$ & $7.29 \pm 0.36$ & $60.11 \pm 0.540$ \\
\hline
\end{tabular}




\begin{tabular}{ccllllll}
\hline & Vitamin C & $0.023 \pm 0.001$ & $0.0042 \pm 0.0003$ & $0.027 \pm 0.001$ & $0.005 \pm 0.0006$ & $8.17 \pm 0.44$ & $61.76 \pm 0.556$ \\
Vitamin E & $0.023 \pm 0.001$ & $0.0043 \pm 0.0005$ & $0.026 \pm 0.002$ & $0.004 \pm 0.0005$ & $8.51 \pm 0.97$ & $61.04 \pm 1.177$ \\
Nucleotides & $0.020 \pm 0.002$ & $0.0048 \pm 0.0007$ & $0.0238 \pm 0.001$ & $0.0038 \pm 0.0004$ & $7.18 \pm 0.39$ & $60.67 \pm 1.003$ \\
DNA & $0.025 \pm 0.002$ & $0.0046 \pm 0.00$ & $0.0267 \pm 0.0019$ & $0.0043 \pm 0.0005$ & $8.15 \pm 0.38$ & $61.29 \pm 1.992$ \\
& Control & $0.020 \pm 0.001$ & $0.0044 \pm 0.0005$ & $0.023 \pm 0.002$ & $0.004 \pm 0.0002$ & $7.08 \pm .0045$ & $61.20 \pm 0.630$ \\
& Vitamin C & $0.020 \pm 0.0004$ & $0.0046 \pm 0.0003$ & $0.022 \pm 0.001$ & $0.004 \pm 0.004$ & $7.60 \pm 0.50$ & $62.49 \pm 0.850$ \\
III & Vitamin E & $0.0230 \pm 0.003$ & $0.004 \pm 0.0002$ & $0.027 \pm 0.002$ & $0.004 \pm 0.0002$ & $9.38 \pm 1.66$ & $62.17 \pm 0.929$ \\
& Nucleotides & $0.025 \pm 0.002$ & $0.0046 \pm 0.0003$ & $0.022 \pm 0.001$ & $0.004 \pm 0.0003$ & $8.06 \pm 0.62$ & $61.67 \pm 2.420$ \\
& DNA & $0.023 \pm 0.0009$ & $0.004 \pm 0.0003$ & $0.023 \pm 0.002$ & $0.004 \pm 0.0003$ & $7.84 \pm 0.19$ & $63.94 \pm 0.314$ \\
\hline
\end{tabular}

Table 5. Evaluation of Economic effects of immune modulators using European Production Efficiency Factor (EPEF).

\begin{tabular}{cccc}
\hline Treatments & EFEP Experiment 1 & EFEP Experiment 2 & EFEP Experiment 3 \\
\hline Control & 341 & 337 & 300 \\
Vitamin C & 364 & 359 & 346 \\
Vitamin E & 381 & 381 & 357 \\
Nucleotides & 384 & 384 & 357 \\
DNA & 377 & 372 & 348 \\
\hline
\end{tabular}

EPEF $=$ Mean Live Body Weight $(\mathrm{kg}) \times$ Livability $(\%) /$ Age $^{*} \times \mathrm{FCR} \times 100$

${ }^{*} 42$ days in these experiments

\section{DISCUSSION}

In experiment I, II and III, significant effect $(\mathrm{P}<0.05)$ of immune modulators on growth performance (AWG, ADG and FCR) was noted as compare to control. Amongst supplements (nucleotide, vitamin $\mathrm{C}$, vitamin $\mathrm{E}$ and DNA), best growth performance was observed in nucleotides groups simultaneously in all three experiments. The results of the present experiments are in accordance with the findings of many researchers (Kejie et al., 2014; Suganya et al., 2015; Cheng et al., 2017; Hossain et al., 2018), reporting that the dietary supplementation of vitamin $\mathrm{E}$ showed positive impact on productive performance, weight gain and FCR of broiler chickens. Vitamin E supplemented broiler chicken diets may decrease stress by reducing the catabolic reaction of the body and, in that way, spare nutrients otherwise utilized for combating the stress and enhanced growth and increased body weight (Bhatti et al. 2016;).

The findings are also in agreement with the observations of Ismail et al. (2014); Bhatti et al. (2016); and Selvam et al. (2017) whom supplemented vitamin E in the diet of broiler chickens and noted improvement in growth, compared to the birds not offered vitamin E, whereas, vitamin $\mathrm{E}$ supplementation showed nonsignificant effect on feed intake (Ismail et al., 2014). In the same context, higher daily gain, superior body weight, better FCR were observed in broiler chicken supplemented vitamin $\mathrm{C}$ diet compared to control group (Kutlu and Forbes 1993'; Kutlu and Forbes 19932; Sahin et al., 2003; Imik et al., 2012; Motasem, 2012; Zeferino et al., 2015). Similarly, the addition of vitamin $\mathrm{C}$ and vitamin $\mathrm{E}$ in diet showed enhanced growth performance in broilers. Sheikh et al., (2020); Khattak et al., (2012) and Lohakare et al. (2005) reported that feed supplemented with ascorbic acid have strong economic impact as well as improvement in growth performance of broilers.

Contrary to our results, addition of dietary ascorbic acid in combination with vitamin $\mathrm{E}$ as feed supplement did not improved body weight gain and FCR (Ali et al., 2010; Jang, 2014; Ali, 2012). Surprisingly, significant reduction in feed intake and improved body weight and feed conversion ratio was observed with vitamin $\mathrm{E}$ in diet (Habibian et al., 2016; Habibian et al., 2014; Leskovec et al., 2018). These differences in results might be due to variations in the experimental duration, management practices adopted during rearing of birds, source of vitamins and nucleotides, strain of broiler breed and also the environmental conditions that were maintained during the experiments (Baracho et al., 2018). Endogenous production of nucleotides might become inadequate because a considerable energy is essentially required for de novo production of nucleotides (Hess et al., 2012; Wu et al., 2018). In the present study, supplementation of nucleotides significantly improved the growth performance indices of birds and showed higher WG (4.62\% and 4.14\%) experimental groups I, II and III respectively than the control. Similar to these findings, previously the supplemented yeast nucleotide improved live weight gain and FCR during early growth phase (1 to 10) compared to that of control birds (Grimble et al., 2001; Morales et al., 2010; Yalçin et al., 2013; Huff et al., 2013b). Similar results have been reported by several other researchers (Esteve et al., 2007; Chiofalo et al., 2011). However, observations of Alizadeh et al., (2016) are contrary to our findings who reported non-significant effect of nucleotide 
supplementation on broiler chicken growth performance. The variations might be due to the source of nucleotides used in the experiment (Esteve et al., 2007). Addition of immune modulators had non-significant effect on relative organ weight of liver, gizzard, proventiculous, and intestinal length and carcass percentages in all three experiments. Findings are in hand with other scientists (Hernandez et al., 2004). Islam ${ }^{1}$ et al., 2004 used probiotics and plants extract in their studies and observed no significant effect on visceral organs. Furthermore, improvement in growth performance of broiler chicken directly or indirectly with the supplementation of immune modulators might be related to improved immune status of the birds, reduced nutrient lose that might have been used to maintain certain immune status (Sarangarajan et al., 2017; Niki, 2015; Islam $^{2}$ et al).

Conclusions: Based on results, it can be concluded that the supplementation of immune modulators either in the starter or finisher phase had positive impact on growth parameters which ultimately results in better profit margins.

\section{REFERENCES}

Ajuwon, Olawale Razaq, and O. M. O. Idowu (2010). Vitamin $\mathrm{C}$ attenuates copper-induced oxidative damage in broiler chickens. African J. Biotechnology 9(44), 7525-7530.

Ali, M. T., M. A. R. Howlider, A. K. Azad, and M. S. Rahman (2010). Vitamin C and electrolyte supplementation to support growth and meat yield of broilers in a hot humid environment. J. The Bangladesh Agricultural University 8(452), 35751.

Ali, N (2012). The effects of different levels of poultry fat with vitamin $\mathrm{E}$ on performance and carcass traits of broilers. Afr. J. Agric. Res. 7, 14201424.

Alizadeh, M., J. C. Rodriguez-Lecompte, A. Yitbarek, S. Sharif, G. Crow, and B. A. Slominski (2016). Effect of yeast-derived products on systemic innate immune response of broiler chickens following a lipopolysaccharide challenge. Poultry science 95(10), 2266-2273.

Baracho, M.S., I.A. Nääs, P.S. Betin, and D.J. Moura (2018). Factors that Influence the Production, Environment, and Welfare of Broiler Chicken: A Systematic Review. Brazilian J. of Poultry Science, 20(3), 617-624.

Bhatti, N., Z. Hussain, M. Mukhtar, A. Ali, M. Imran, A. Rafique, S. Manzoor, and S. Rehman (2016). Effects of vitamins $\mathrm{E}$ and $\mathrm{C}$ supplementation on the immune response of broiler chicks. J. Antivir. Antiretrovir 8, 151-154.
Kejie, Chen, Xi Peng, Jing Fang, Hengmin Cui, Zhicai Zuo, Junliang Deng, Zhengli Chen et al. (2014). Effects of dietary selenium on histopathological changes and $\mathrm{T}$ cells of spleen in broilers exposed to aflatoxin B1. International J. Environmental Research and Public Health 11(2), 1904-1913.

Chen, Yueping, Yefei Cheng, Chao Wen, Yuru Kang, Aiqin Wang, and Yanmin Zhou (2018). Effects of dietary synbiotic supplementation as an alternative to antibiotic supplementation on the growth performance, carcass characteristics, meat quality, immunity and oxidative status of cherry valley ducks. The J. Poultry Science 0170128 .

Cheng, K., Z. H. Song, X. C. Zheng, H. Zhang, J. F. Zhang, L. L. Zhang, Y. M. Zhou, and T. Wang (2017). Effects of dietary vitamin E type on the growth performance and antioxidant capacity in cyclophosphamide immunosuppressed broilers. Poultry science 96(5), 1159-1166.

ChioFalo, Biagina, V. Lo Presti, G. Samoini, V. Chiofalo, and L. Liotta (2011). Nucleotides in broiler chicken diet: effect on breast muscles quality. Czech J. Food Sciences 29(4), 308-317.

Corsello, Tiziana, Narayana Komaravelli, and Antonella Casola (2018). Role of hydrogen sulfide in NRF2-and sirtuin-dependent maintenance of cellular redox balance. Antioxidants 7(10), 129.

Kuldeep Dhama,, Ruchi Tiwari, Rifat Ullah Khan, Sandip Chakraborty, Marappan Gopi, Kumaragurubaran Karthik, Mani Saminathan, Perumal Arumugam Desingu, and Lakshmi Tulasi Sunkara (2014). Growth promoters and novel feed additives improving poultry production and health, bioactive principles and beneficial applications: the trends and advancesa review. Int J Pharmacol 10(3), 129-159.

D'Costa, V. M., C. E. King, L. Kalan, M. Morar, W. W. Sung, C. Schwarz, D. Froese, G. Zazula, and F. Calmels (2011). 411 Debruyne R, Golding GB, Poinar HN, Wright GD. Antibiotic resistance is ancient. Nature 412(477), 457-61.

Esteve-Garcia, E., D. Martinez-Puig, E. Borda, and C. Chetrit (2007). Efficacy of a nucleotide preparation in broiler chickens. In Proceedings 16th European Symposium on Poultry Nutrition. Strasbourg, France, pp. 511-514.

Grimble, George K., and Olwyn M. Westwood (2001). Nucleotides as immunomodulators in clinical nutrition. Current Opinion in Clinical Nutrition \& Metabolic Care 4(1), 57-64.

Habibian, Mahmood, Shahab Ghazi, Mohammad Mehdi Moeini, and Alireza Abdolmohammadi (2014). Effects of dietary selenium and vitamin $\mathrm{E}$ on immune response and biological blood parameters of broilers reared under 
thermoneutral or heat stress conditions. International J. Biometeorology 58(5), 741-752.

Habibian, Mahmood, Shahab Ghazi, and Mohammad Mehdi Moeini (2016). Effects of dietary selenium and vitamin $\mathrm{E}$ on growth performance, meat yield, and selenium content and lipid oxidation of breast meat of broilers reared under heat stress. Biological trace element research 169(1), 142-152.

Hernandez, F., Jl Madrid, V. Garcia, J. Orengo, and M. D. Megias (2004). Influence of two plant extracts on broilers performance, digestibility, and digestive organ size. Poultry science 83(2), 169-174.

Hess, Jennifer R., and Norman A. Greenberg (2012). The role of nucleotides in the immune and gastrointestinal systems: potential clinical applications. Nutrition in Clinical Practice 27(2), 281-294.

Hossain, Md Sakhawat, Shunsuke Koshio, Manabu Ishikawa, Saichiro Yokoyama, Nadia Mahjabin Sony, Serge Dossou, and Weilong Wang (2018). Influence of dietary inosine and vitamin $\mathrm{C}$ supplementation on growth, blood chemistry, oxidative stress, innate and adaptive immune responses of red sea bream, Pagrus major juvenile. Fish \& shellfish immunology 82, 92100.

Huff, G. R., W. E. Huff, I. V. Wesley, N. B. Anthony, and D. G. Satterlee (2013a). Response of restraint stress-selected lines of Japanese quail to heat stress and Escherichia coli challenge. Poultry science 92(3), 603-611.

Huff, G. R., W. E. Huff, S. Jalukar, J. Oppy, N. C. Rath, and B. Packialakshmi (2013b). The effects of yeast feed supplementation on turkey performance and pathogen colonization in a transport stress/Escherichia coli challenge. Poultry science 92(3), 655-662.

Imik, Halit, H. Ozlu, R. E. C. E. P. Gumus, M. Aydemir Atasever, S. Urcar, and M. Atasever (2012). Effects of ascorbic acid and $\alpha$-lipoic acid on performance and meat quality of broilers subjected to heat stress. British Poultry Science 53(6), 800-808

Ismail, F., M. El-Gogary, and Ml El-Nadi (2014). Influence of Vitamin E supplementation and stocking density on performance, thyroid status, some blood parameters, immunity and antioxidant status in broiler chickens. Asian J. Anim. Vet. Adv 9, 702-712.

Islam 1, M. W., M. M. Rahman, S. M. L. Kabir, S. M. Kamruzzaman, and M. N. Islam (2004). Effects of probiotics supplementation on growth performance and certain haemato-biochemical parameters in broiler chickens. Bangladesh $\mathrm{J}$ Vet. Med. 2(1), 39-43.

Islam $^{2}$, M. S., M. E. R. Bhuiyan, M. I. A. Begum, M. A. Miah, and M. Myenuddin (2004). Effects of vitamin-mineral premix supplementation on body weight and certain haemato-biochemical values in broiler chickens. Bangladesh J. Vet. Med. 2(1), 45-48

Jang, In-Surk, Young-Hyun Ko, Yang-Soo Moon, and Sea-Hwan Sohn (2014). Effects of vitamin C or $\mathrm{E}$ on the pro-inflammatory cytokines, heat shock protein 70 and antioxidant status in broiler chicks under summer conditions. AsianAustralasian J. Anim. Sciences 27(5), 749.

Khattak, Farina Malik, Thomas Acamovic, Nicholas Sparks, Talat Naseer Pasha, Mussarat Hussain Joiya, Zafar Hayat, and Zulifqar Ali (2012). Comparative efficacy of different supplements used to reduce heat stress in broilers. Pakistan J. Zoology 44(1), 1-5.

Kutlu', H.R., J.M. Forbes (1993). Self-selection of ascorbic acid in coloured foods by heat-stressed broiler chicks. Physiol Behav. 53, 103-110.

$\mathrm{Kutlu}^{2}$, H.R., J.M. Forbes (1993). Changes in Growth and Blood Parameters in Heat Stressed Broiler Chicks in Response to Dietary Ascorbic Acid. Livest. Prod. Sci. 36, 335-350.

Leskovec, J., A. Levart, A. Nemec Svete, L. Perić, M. Đukić Stojčić, D. Žikić, J. Salobir, and V. Rezar (2018). Effects of supplementation with $\alpha$ tocopherol, ascorbic acid, selenium, or their combination in linseed oil-enriched diets on the oxidative status in broilers. Poultry science 97(5), 1641-1650.

Lohakare, J. D., J. K. Kim, M. H. Ryu, T-W. Hahn, and B. J. Chae (2005). Effects of vitamin C and vitamin $\mathrm{D}$ interaction on the performance, immunity, and bone characteristics of commercial broilers. J. Applied Poultry Research 14(4), 670-678.

Morales-López, R., E. Auclair, Filip Van Immerseel, Richard Ducatelle, F. García, and J. Brufau (2010). Effects of different yeast cell wall supplements added to maize-or wheat-based diets for broiler chickens. British poultry science 51(3), 399-408.

Motasem, A.M (2012). Effects of Vitamin C and Zinc on Broilers Performance of Immunocompetence under heat stress. Asian J. Anim. Sci. 6, 76-84.

Niki, E (2015). Evidence for beneficial effects of vitamin E. The Korean J. Internal Medicine, 30(5), 571.

Owosibo, A. O., O. M. Odetola, O. O. Odunsi, O. O. Adejinmi, and O. O. Lawrence-Azua (2013). Growth, haematology and serum biochemistry of broilers fed probiotics-based diets. Afr J Water Conserv Sustain 1 61-65. 
Rafeeq, M., Rashid, N., Tariq, M. M., Tareen, R. B., Ullah, A., \& Mustafa, Z. (2017). Evaluation of Alternatives to Antibiotic Feed Additives in Broiler Production. Pakistan J. Zool., 49(3).

Sheikh, Irfan Shahzad, Masroor Ahmad Bajwa, Nadeem Rashid, Muhammad Zahid Mustafa, Mohammad Masood Tariq, Majed Rafeeq, Abdul Samad, Tauseef M. Asmat, and Asad Ullah (2020). Effects of Immune Modulators on the Immune Status of Broiler Chickens. Pakistan J. Zool. 52(3), 1095.

Sahin, K., M. Onderci, N. Sahin, M. F. Gursu, and O. Kucuk (2003). Dietary vitamin C and folic acid supplementation ameliorates the detrimental effects of heat stress in Japanese quail. The J. Nutrition 133(6), 1882-1886.

Sahin, N., K. Sahin, and O. Kucuk (2001). Effects of vitamin $\mathrm{E}$ and vitamin $\mathrm{A}$ supplementation on performance, thyroid status, and serum concentrations of some metabolites and minerals in broilers reared under heat stress $(320 \mathrm{C})$. VETERINARNI MEDICINA-PRAHA- 46(11), 286-292.

Santoro, M. M (2018). Fashioning blood vessels by ROS signalling and metabolism. In Seminars in cell \& developmental biology (80, pp. 35-42). Academic Press.

Selvam, R., M. Saravanakumar, S. Suresh, G. Sureshbabu, M. Sasikumar, and D. Prashanth (2017). Effect of vitamin E supplementation and high stocking density on the performance and stress parameters of broilers. Brazilian J. Poultry Science 19, no. 4 587-594.

Suganya, T., S. Senthilkumar, K, Deepa, R. Amutha (2015). Nutritional management to alleviate heat stress in broilers. Int J Sci Environ Technol. 4, 661-666.

Surai, P. F., I. I. Kochish,., V. I. Fisinin,and M.T. Kidd. (2019). Antioxidant defence systems and oxidative stress in poultry biology: An update. Antioxidants, 8(7), 235.

Sarangarajan, R., S. Meera., R. Rukkumani., P. Sankarand G- Anuradh (2017). Antioxidants:
Friend or foe?. Asian Pacific J. Tropical Medicine, 10(12), 1111-1116.

Valenzuela-Grijalva, Nidia Vanessa, Araceli PinelliSaavedra, Adriana Muhlia-Almazan, David Domínguez-Díaz, and Humberto González-Ríos (2017). Dietary inclusion effects of phytochemicals as growth promoters in animal production. J. Animal Science and Technology 59(1), 8 .

Vlojc, M., T. Frankič, A. Levart, M. Nemec, and J. Salobir (2011). Evaluation of different vitamin E recommendations and bioactivity of $\alpha$ tocopherol isomers in broiler nutrition by measuring oxidative stress in vivo and the oxidative stability of meat. Poultry science $90(7)$ 1478-1488.

Watson, Ronald Ross, and Fabien De Meester, eds (2016). Handbook of cholesterol: Biology, function and role in health and diseases. 11. Wageningen Academic Publishers.

$\mathrm{Wu}$, Che, Zhenwei Yang, Cailiang Song, Chao Liang, Hongxin Li, Weiguo Chen, Wencheng Lin, and Qingmei Xie (2018). Effects of dietary yeast nucleotides supplementation on intestinal barrier function, intestinal microbiota, and humoral immunity in specific pathogen-free chickens." Poultry science 97(11), 3837-3846.

Yalçın, S., H. Eser, S. Yalçın, S. Cengiz, and Ö. Eltan (2013). Effects of dietary yeast autolysate (Saccharomyces cerevisiae) on performance, carcass and gut characteristics, blood profile, and antibody production to sheep red blood cells in broilers. J. Applied Poultry Research 22(1), 55-61.

Zeferino, C. P., C. M. Komiyama, V. C. Pelícia, V. B. Fascina, M. M. Aoyagi, Luiz Lehmann Coutinho, J. R. Sartori, and A. S. A. M. T. Moura (2016). Carcass and meat quality traits of chickens fed diets concurrently supplemented with vitamins $\mathrm{C}$ and $\mathrm{E}$ under constant heat stress. animal 10(1), 163-171. 